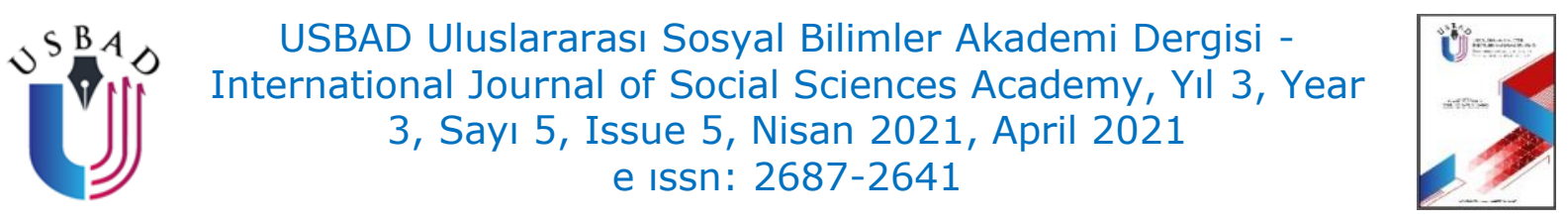

\title{
REPRESENTATION AND JUSTICE
}

\author{
TEMSİL VE ADALET
}

\begin{abstract}
Ziynet BAHADIR
Dr., Öğr., Üyesi, Sivas Cumhuriyet Üniversitesi, Sosyoloji Bölümü,

Sivas/Türkiye.

Assoc., Prof., Sivas Cumhuriyet University, Department of Sociology, Sivas/Turkey.

bahadir@cumhuriyet.edu.tr
\end{abstract}

ORCID ID: 0000-0002-7905-8007

\section{Makale bilgisi | Article Information}

DOI: $10.47994 /$ usbad.926408

Makale Türü / Article Type: Araştırma Makalesi / Research Article

Geliş Tarihi / Date Received: 22.04.2021

Kabul Tarihi / Date Accepted: 29.04.2021

Yayın Tarihi / Date Published: 20.04.2021

Yayın Sezonu / Pub Date Season: Nisan / April

Bu Makaleye Atıf İçin / To Cite This Article: Bahadır, Z. (2021). Representation and Justice. USBAD Uluslararası Sosyal Bilimler Akademi Dergisi $3(5), 784-803$.

Intihal: Bu makale intihal.net yazılımınca taranmıştır. İntihal tespit edilmemiştir. Plagiarism: This article has been scanned by intihal.net. No plagiarism detected.

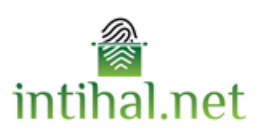

İletişim: Web: https://dergipark.org.tr/tr/pub/usbad mail: usbaddergi@gmail.com 
Abstract: In this paper, the regulations in the electoral system will be analyzed in terms of the problem of justice in representation. It cannot merely be reduced to election, but democracy is distinguished from other regimes with the right/freedom to vote and stand for election of the equal citizens. The relation between democracy and electoral system, which is a technical regulation, is also important. One of the two principles that must be present in the electoral system is emphasized to be "Justice in Representation" and the other is "stability in administration. "Stability" may be prioritized especially in developing countries, and some practices which harm the principle of "justice" may be seen. For example, it is not quite possible to see "justice in representation" in practice in Turkey because of the election threshold discussed to be lowered lately but not realized somehow. There have been some people with a negative view on the elections who believe that their votes will go for nothing due to the application of threshold. The vote rate that the political parties obtain and representation rate of them in the assembly are important data from the point of view of the rate of being represented. Again for example, some applications such as "quota of women" which will overcome gender apartheid become a current issue, making positive discrimination, and it can be discussed in terms of democratic principles. The right of being represented which has turned into a problem of "justice" can be regarded as identical with democracy, however, it must be indicated that it is necessary to have "representation" and "justice" simultaneously and the principle of "justice in representation" is of as vital importance as at least the principle of "administrational stability."

Keywords: Democracy, Electoral System, Election Threshold, Justice in Representation, Administrational Stability

Öz: Bu yazıda, seçim sisteminde var olan düzenlemeler, temsilde adalet sorunu bakımından irdelenecektir. Yalnızca seçime indirgenemez ama demokrasi, eşit yurttaşların seçme ve seçilme hakkı/özgürlüğü ile diğer rejimlerden ayrılır. Teknik bir düzenleme olan seçim sistemi ile demokrasi arasındaki ilişki de önemlidir. Seçim sisteminde olması gereken iki ilkeden biri, "temsilde adalet"; diğeri, "yönetimde istikrar" olarak belirtilir. Özellikle gelişmekte olan ülkelerde "istikrar" ön planda tutulabilmekte, "adalet" ilkesini zedeleyen uygulamalar görülebilmektedir. Örneğin, Türkiye'de, düşürülmesi son dönemlerde çok tartışılsa da bir türlü gerçekleştirilmeyen yüksek seçim barajı nedeniyle, "temsilde adalet" ilkesi uygulamada pek görülmemektedir. Baraj uygulaması nedeniyle oylarının boşa gideceğini düşünerek seçimlere bakışı olumsuz olan insanlar bulunmaktadır. Siyasal partilerin, seçimlerde aldığı oy oranı ve mecliste temsil edilebilme oranı da adalet ilkesi bakımından önemli veridir. Yine örneğin, cinsiyet ayrımcılığını giderecek biçimde "kadın kotası" gibi uygulamalar da "pozitif ayrımcılık" yapılarak gündeme gelmekte, demokratik ilkeler açısından tartışılabilmektedir. Bir "adalet" sorununa dönüşen temsil edilebilme hakkı, demokrasi ile özdeş görülebilir ancak; demokrasi için "temsil" ve "adalet"in bir arada olması gerektiği; "temsilde adalet 
ilkesi"nin, en az "yönetimde istikrar" ilkesi kadar öncelikli önem taşıdığı belirtilmelidir.

Anahtar Kelimeler: Demokrasi, Seçim Sistemi, Seçim Barajı, Temsilde Adalet, Yönetimde İstikrar

\section{INTRODUCTION}

In parliamentary democracy, it is ultimate that the governed people elect the governors. Election and parliament are in general the subject of politics; when they are taken into consideration together with some concepts such as "justice" and "representation, social dimensions gain currency. The importance of social participation in democracies is indisputable. Election is not the only way of social participation; the citizens may take part in politics either more or less intensively, however many citizens may be contented with showing the behavior of social participation as a "voter". Being a voter is a sociologic condition as well as being a political means. It is defined as democracy in modern societies that parliament, which has the function of forming and implementing the law, is composed of the people chosen by the public. The details of representation in parliament and its discussion are thus caused by the sensitiveness of this power of transfer.

\section{ELECTION AND DEMOCRACY}

The answers given to some questions present in all of the human societies such as the quality of the distinction between governed and the governor, how the governors were elected, whether their authorities are limited or not, bring the types of political regimes into question. Duverger(1986: 9-11) indicates that the most important issue in the distinction of various types of political regimes which he defined in the broadest sense as the shape of the distinction between the governed and the governors and as the governing structure of the nation in its narrowest sense is whether the governors come to the power by means of general and fair elections or not.

Notwithstanding that there are various types of idealized democracy (such as direct democracy, representative democracy, social democracy), it is seen that "participatory" and "pluralistic" democracies dominate in our present day. In one sense, democracy is both the regime which is regarded as the best one among the political regimes and which is continuously developed one.

According to Selçuk (1987: 10-11), the common religion of today's human beings is democracy. Democracy depends on awakening of the people on the subjects of rights, freedom and responsibilities and 
awakening depends on the prevalence of participation. "The age of political participation" which is experienced on the whole world is one of the blessings of social development.

According to Touraine (1997: 45), cannot be reduced to procedures. It is necessary that the basic rights of the individuals are secured and they participate in social life as citizens. The two worlds which must remain separate - the state and the society- must also be interconnected by means of the representation of political administrators. The following three dimensions complete each other: Respect to fundamental rights, citizenship and representation of political administrators; the mutual dependency relationship among these constitute democracy. Considering that civil society is composed of a lot of social actors, democracy allow for representation to the extent that it is pluralistic. Touraine indicates with these determinations that "pluralistic" understanding constitutes democracy.

Indeed, it can be considered that societies, in which the mechanisms providing the citizens, who use "the right to vote and stand for election" which takes part among basic rights, with the chance of conveying the needs and demands of civil society to the administrators they elected are held open and in which there is not a "majoritarian" but "pluralistic" structure, are democratically governed.

To be able to use political rights which are among "the first-generation rights", also called as "the classical rights" but outside of individual and collective freedoms, it is necessary to be a citizen of a state. Political rights have also been guaranteed in the constitution and supranational texts. There are regulations about this subject in ECHR (European Convention on Human Rights) and International Covenant on Civil and Political Rights (Kaboğlu, 1994: 232).

In addition, it is possible to say that international organizations have created some control mechanisms (for example AGIT sends electoral watchdogs) and this will affect the reliability of the elections positively. However, apart from these and above all the citizens must be aware of their political rights and freedoms. In this way, the connection of the thought of democracy with society in terms of political sociology will get stronger.

$67^{\text {th }}$ article of the 1982 Constitution titled "Right to vote, to be elected and to engage in political activity" pertains to Citizens' right to vote, to be elected, and to engage in political activities independently or in a political party, and to take part in a referendum in conformity with the conditions set forth in the law. According to this, elections and referendums are held 
under the direction and supervision of the judiciary, according to the principles of free, equal, secret, direct, universal suffrage, and public counting of the votes. The use of these rights are regulated by law. Electoral laws are designed so as to reconcile the principle of fairness in representation and governmental stability (Kili ve Gözübüyük, 2000: 84).

Despite this provision in the constitution, in practice it is not always possible to see these principles together. It is seen that the applied election systems have impact on this. According to, which one of the election systems (majority system or proportional representation system) and how it is applied, the reflection of vote rates to the parliament may change. According to Tuncer (2006) who explained the situation that some parties are represented over their vote rate and some are represented below their vote rates and that some parties stay out of the parliament as their vote rates are not sufficient with "overrepresentation" or "under-representation", over or under representation rates are in low levels in the systems that give priority to fairness in representation. However in the systems that give priority to governmental stability these rates increase."

\section{ELECTORAL SYSTEMS}

Apart from the fact that the principle of "election" is distinguishing, it is also asserted that it has a restrictive effect. "As every justice discussion is basically a discussion related to injustice, the discussion of fairness in representation is also a reaction to this restrictive effect of the election system. All the election processes seek an answer for three basic questions: "What will be elected, who will be elected and how they will be elected? Though the discussion of fairness in representation focuses on the third question, that is to say the problems in the process of turning the votes into number of the members in the parliament" (Aytaç, 2011: 14), it has also been indicated that there are also some other restrictions. For example, because of unseen obstacles, the struggle continues on the subject of being the one elected; again the practice of "quotas for women" is seen against gender apartheid which is among the typical, universally widespread justice problems. When mass voters came into existence in most parts of the world with the struggle of general and equal vote, the control of the power of the voters by means of technical devices of the election process was seen in this instance and the discussion of fairness in representation occurred.

These discussions are not related to the theoretical; they are related to concrete problems encountered in social life and important. Election system which is a technical regulation determined by the governors of the society determines whether the reflection of the votes on the parliament 
crates a fair representation or not. The same rate of vote, according to the use of proportional representation and majority system may lead to the occurrence of different majorities but both of the systems may be used legally. (...) in the countries which majority system is used in the sue of simple or absolute majority or the preference of counting methods such as national remainder system or d'Hondt system and sometimes the addition of election thresholds determine on a vast scale what kind of majority will come into existence" (Aytaç, 2011: 16). Thereby, it is possible that the struggle against election thresholds and etc. is regarded as the reflection of people's demand of equality in the democratic system just like the struggle given and being given for general, equal and free vote.

Election systems are split up as majority system proportional representation. In the historical process majority system was first implemented, then proportional representation has replaced it and sometimes there have been some systems as the mixture of both.

\section{a. Majority System}

It will be sufficient to give the information about majority system summarizing from Özbudun (1990: 229-231). Majority system is divided into two as "alternative vote" and according to the greatness 'the voting district' and 'single member district'. In the alternative vote system only one person for each voting district is elected. But for the single member district' which is used in most countries, electoral districts would have various numbers of deputies according to their population. In the alternative vote method, there are "karma liste", "closed list" and "preferential voting". Another difference is according to the way by which the votes are evaluated. This is a widely known distinction known as "majority system" or "proportional representation system". Simple majority system with oneround especially when used with Party List Voting gives results not suitable to the principle of justice in the elections. This system reflects the difference between the vote rates of the parities to the parliament in a muchexaggerated way. The second form of the majority method is the absolute or the two-round majority system and in this system if a party gains the absolute majority of the votes in an electoral district, it wins the elections and there is no need for the second round but if none of the parties are able to reach an absolute majority the second round is realized after a certain period of time. The election system with two-round is an outmoded system.

The application of majority system is simple. It increases the participation and it minimizes the number of invalid votes. As there are generally the government party and the opposition party in the parliament 
the stability is provided. The fact that the governments established without the need of coalition take stable decisions also increases the trust in the governors. Especially in elections with single member district, the voters and the candidates are closely associated with each other and the votes are cast for the character of the candidates. The candidates are the people who are aware of this fact, having the responsibility of this and who know the problems of their district in which they are elected. The chance of independent candidates is also high. Besides these advantages, the system has also some drawbacks. First of all, the inequality between the number of the votes and the number of the representatives in the parliament creates some problems such as under-representation of the minority, overrepresentation of the majority and votes' going waste. The people coming from single member districts are either the important figures of the district or the people supported by them and as these people represent mainly themselves they may go out of party discipline. As to two-round the election system, there may occur some small parties for the possibility of creating a coalition and even the agreements made for the second-round may turn into bargaining. The government with majority may create a parliament dictatorship on the basis of it majority in the parliament abusing the government (Sezen, 2000: 172-179).

The point which must be specifically emphasized is that legitimacy of the representatives in the conscious of the society is also important though a powerful government with majority in the parliament is important in terms of stability of the government in representative democracy. The expectation of the people voting in the society is the reflection of their votes to the parliament. As society want to see the institutionalization of the justice in state legislature, it creates trouble if the number of the people remained out of parliament is high. In addition, the most negative of them is the possibility that it may have an oppressive attitude depending on its majority in the parliament.

\section{b. Proportional Representation System}

Proportional representation means that every party will have equal representative number with the proportion of their votes. Subtypes of proportional representation may be "Largest Remainder Approach" or "national remainder system" according to how the votes are distributed and it may either be d'Hondt system which took its name from a Belgian mathematician. In Turkey, d'Hondt system with a threshold has been used since 1968. It is no doubt that the threshold is for the benefit of big parties (Özbudun, 1990: 231-236). 
If its details are set aside, the aim of the proportional representation system is to give every party a possibility of being represented proportional to their numerical power. It is possible summarize the advantages and the disadvantages of this system as the following (Sezen, 2000: 204-208), equality in representation supports the view that representation system is a fair system. The number of the unrepresented people is low and overrepresentation is rarely seen. Every view, every ideology present in the society is represented including those of minorities and thus democratic plurality is possible. Voters are eager to take part in the elections. As to the disadvantages of the proportional representation system, it has a tendency to increase the number of the parties in the country. Coalition governments are established as a single party cannot have the majority in the parliament. When there are contradictions in making and applying government program in coalitions, there appear crises frequently and the country experiences a state of political instability.

The application of majority system and proportional representation system leads to a set of results. "Majority system leads to quite unfair results in the countries where there are various parties representing distinct political, social and economic views. This system does not give the chance of being represented to the views in minority and even to the strong minorities with a number just one under the half of the voters. Thus, it creates a situation in which a party seemingly with the majority in the parliament cannot represent the majority in the society. What's worse, in the countries especially where democratic conventions are not well established, there are not curbing and institutionalized control mechanisms which would assure rights and freedoms, the party which captured the majority may easily have the possibility of abusing the governmental power (Tanilli, 1985: 270). That's why, proportional representation system is used in many countries. Thus, proportional representation system in which the distribution of seats corresponds closely with the proportion of the total votes cast for each party is regarded as the one that can reflect the general vote more and thus much fairer, though it has some drawbacks such as the inflation of the parties and being able to cause instability of the government.

In proportional representation system, the enforcement of threshold with the aim of preventing the inflation of the parties is at different rates in different countries. The highest threshold is in Turkey, the Russia. In many western democracies this rate is between $2 \%$ and $4 \%$. As is known, political parties complain of the election threshold of $10 \%$ used in the elections when they remain out of parliament and are victims, but when they make the cut and get the power, the situation changes. Though they bring up the problem 
of representation when they are under the threshold, it can be seen that they are a side of parliamentary dictatorship in a way that shows their inner conflicts when they come to power. Therefore, though fairness in representation is considered to be a sociologic issue, the discussions go over political benefits.

The idea that it is necessary in terms of justice that the election threshold which is considered to be very high by the public should be lowered to $5 \%$ or below is widely accepted. In an interview with Tarhan Erdem, who is known for his political studies, when asked 'which one is the ideal or most close to ideal election system in terms of fairness in representation', he answered as: "The system in which the principle of fairness in representation came to the forefront most is 'National Remainder System' which was used in 1965 (...) if the election threshold is lowered to $3 \%$, the election system would be turned into a fair one" (Bora, 2011: 21). Erdem also indicates that sensitiveness on fairness in representation is more widely known in the recent years.

Göksel ve Çınar indicate that the real question to be answered on the issue of the threshold, the decrease of which has been discussed is whether the principle of governmental stability really derives great benefits while compromising fairness in representation, or whether it is possible to increase (substantially) "fairness in representation" without compromising governmental stability. Göksel ve Çınar (2011) using the results of 1995, 1999, 2002 and 2007 elections and measuring these two principles objectively assert that a threshold of $4 \%$ is optimal. Accordingly, it is seen that fairness in representation gets significantly better with the decrease of the threshold to $4 \%$ and there is not much loss in governmental stability.

\section{Election Systems Implemented in Turkey and their Effects}

In one party era, five general elections were held: in these general elections held in the years 1927, 1931, 1935, 1939 and 1943 "(...) election system did not change much. The second elections, that is to say, 'müntehibi sani's elect the deputies. The candidates are announced by the parities" (Çavdar, 1987: 77).

"1946 elections on which there are much debate has a distinct place in Turkish history of democracy. For one thing this election is the first election in which the voters elect their representatives, in other worlds the deputies directly. The second voters became a thing of the past" (Çavdar, 1987: 82).

In the period between 1946 and 1950 a set of decisions and actions which are important in terms of the process of democratization appeared 
The foundation of an election system under the control of a neutral management (Supreme Election Committee), under the assurance of the law, one-round, depending on the basis of secret vote and open counting and contemporary was laid (Çavdar, 1987:89).

Various system have been used since the beginning of the multi-party system. If it is necessary to list them:

\begin{tabular}{|c|c|}
\hline Election System & $\begin{array}{l}\text { General Parliamentary Election } \\
\text { they were implemented }\end{array}$ \\
\hline \multicolumn{2}{|l|}{ Majority System } \\
\hline $\begin{array}{l}\text { Party List Majority } \\
\text { (The system in which the principle of } \\
\text { governmental stability comes to the } \\
\text { forefront most) }\end{array}$ & $1946,1950,1954,1957$ \\
\hline \multicolumn{2}{|l|}{$\begin{array}{l}\text { Proportional Representation / with } \\
\text { a threshold Systems }\end{array}$} \\
\hline $\begin{array}{l}\text { d'Hondt with double threshold }+ \\
\text { Contingent }\end{array}$ & 1987,1991 \\
\hline d'Hondt with double threshold & 1983 \\
\hline $\mathrm{d}^{\prime}$ Hondt with a threshold of state & $\begin{array}{l}\text { 1995, 1999, } 2002 \text { (since then to } \\
\text { present) }\end{array}$ \\
\hline d'Hondt with a threshold of district & 1961 \\
\hline \multicolumn{2}{|l|}{$\begin{array}{l}\text { Proportional Representation } \\
\text { /without a threshold Systems }\end{array}$} \\
\hline d'Hondt without a threshold & $1969,1973,1977$ \\
\hline $\begin{array}{l}\text { National Remainder } \\
\text { (The system in which the principle of } \\
\text { fairness in representation comes to } \\
\text { the forefront most) }\end{array}$ & 1965 \\
\hline
\end{tabular}

Figure 1: The place it was taken from Tuncer (2006)

As one of fairness of representation and governmental stability principles comes to forefront by force of the election systems, association of these principles in the constitution is set forth; but it couldn't be possible at all times. 
Tuncer (2006) mentions three groups with referent the elections according to the generated results in terms of fairness of representation and governmental stability principles:

(i) The elections in which governmental stability was provided and fairness in representation was ignored.

1950, 1954, 1957, 1987, 2002 elections.

(ii) The elections in which governmental stability and fairness in representation were provided together.

1965, 1969, 1983 elections

(iii) The elections in which fairness in representation was provided but governmental stability wasn't.

1961, 1973, 1977, 1991, 1995, 1999 elections.

According to Tuncer who stated that anticipated targets in terms of governmental stability and fairness in representation could not be realized at all times during the regulation of the election system, the vote rates of the first parties are also important. In addition, state threshold of $10 \%$ leads to the result that a great majority of the votes of the voters couldn't be represented and this means a serious unfairness of representation. All the same, the target of governmental stability cannot be reached at all times; 3 elections out of six of the election systems in which state threshold is valid, the target of single-party government could be reached.

Besides, according to Subaşat (2015), there is a consensus on the view that coalition governments are the source of the political and economic instability. It is a reality that the elections systems implemented to assure single party governments weaken democracy by excluding the smaller parties. Subaşat, who stated that the effects of single-party governments on economic stability and development have not been studied much, mentions the studies which prove the opposite of the popular wisdom. The book published in the year 2011 - depending on the study carried out on 105 countries - has proved that coalition governments are more successful in terms of economic stability and development when compared to singleparty governments. As to Subaşat, in his empirical study including 204 countries and the years between 1975 and 2012, it was determined in a way supporting these data that there were faster economic development and lower inflation.

In the table below which was prepared with the data of TUIK (Turkish Statistical Institute), certain parties' number of votes, vote rates and number of the deputy they gained in the parliament are presented. 
Ziynet Bahadır

\begin{tabular}{|c|c|c|c|c|c|c|c|c|}
\hline $\begin{array}{l}\text { Political } \\
\text { Party }\end{array}$ & 1983 & 1987 & 1991 & 1995 & 1999 & 2002 & 2007 & 2011 \\
\hline $\begin{array}{l}\text { The Number } \\
\text { of } \\
\text { Registered } \\
\text { Voters }\end{array}$ & $\begin{array}{r}19.767 \\
366\end{array}$ & $\begin{array}{r}26.376 . \\
926\end{array}$ & $\begin{array}{r}29.979 . \\
123\end{array}$ & $\begin{array}{r}34.155 .9 \\
81\end{array}$ & $\begin{array}{l}37.49 \\
5.217\end{array}$ & $\begin{array}{r}41.407 \\
.027\end{array}$ & $\begin{array}{r}42.799 . \\
303\end{array}$ & $\begin{array}{r}52.806 \\
322\end{array}$ \\
\hline $\begin{array}{l}\text { The number } \\
\text { of Valid } \\
\text { Votes }\end{array}$ & $\begin{array}{r}17.351 \\
510\end{array}$ & $\begin{array}{r}23.971 . \\
629\end{array}$ & $\begin{array}{r}24.416 . \\
666\end{array}$ & $\begin{array}{r}28.126 .9 \\
93\end{array}$ & $\begin{array}{l}31.18 \\
4.496\end{array}$ & $\begin{array}{r}31.528 \\
.783\end{array}$ & $\begin{array}{r}35.049 . \\
691\end{array}$ & $\begin{array}{r}42.941 \\
763\end{array}$ \\
\hline \multirow{3}{*}{ ANAP } & $\begin{array}{r}7.833 .1 \\
48\end{array}$ & $\begin{array}{r}8.704 .3 \\
55\end{array}$ & $\begin{array}{r}5.862 .6 \\
23\end{array}$ & $\begin{array}{r}5.527 .28 \\
8\end{array}$ & $\begin{array}{r}4.122 \\
929\end{array}$ & $\begin{array}{r}1.618 . \\
465\end{array}$ & - & - \\
\hline & 45,1 & 36,3 & 24,0 & 19,6 & 13,2 & 5,1 & - & - \\
\hline & 211 & 292 & 115 & 132 & 86 & - & - & - \\
\hline \multirow{3}{*}{$\mathrm{HP}$} & $\begin{array}{r}5.285 .8 \\
04\end{array}$ & - & - & - & - & - & - & \\
\hline & 30,5 & - & - & - & - & - & - & - \\
\hline & 117 & - & - & - & - & - & - & - \\
\hline \multirow{3}{*}{ MDP } & $\begin{array}{r}4.036 .9 \\
70\end{array}$ & - & - & - & - & - & - & - \\
\hline & 23,3 & - & - & - & - & - & - & - \\
\hline & 71 & - & - & - & - & - & - & - \\
\hline \multirow{3}{*}{ DYP } & - & $\begin{array}{r}4.587 .0 \\
62\end{array}$ & $\begin{array}{r}6.600 .7 \\
26\end{array}$ & $\begin{array}{r}5.396 .00 \\
9\end{array}$ & $\begin{array}{r}3.745 . \\
417\end{array}$ & $\begin{array}{r}3.008 . \\
942\end{array}$ & - & 64.607 \\
\hline & - & 19,1 & 27,0 & 19,2 & 12,0 & 9,5 & - & 0,2 \\
\hline & - & 59 & 178 & 135 & 85 & - & - & - \\
\hline \multirow{3}{*}{ DSP } & & $\begin{array}{r}2.044 .5 \\
76\end{array}$ & $\begin{array}{r}2.624 .3 \\
01\end{array}$ & $\begin{array}{r}4.118 .02 \\
5\end{array}$ & $\begin{array}{r}6.919 . \\
670\end{array}$ & $\begin{array}{r}384.00 \\
9\end{array}$ & - & 108.089 \\
\hline & & 8,5 & 10,8 & 14,6 & 22,2 & 1,2 & - & 0,3 \\
\hline & & - & 7 & 76 & 136 & - & - & - \\
\hline SHP & & $\begin{array}{r}5.931 .0 \\
00\end{array}$ & $\begin{array}{r}5.066 .5 \\
71\end{array}$ & - & - & - & - & \\
\hline
\end{tabular}

Sayfa | 795 


\begin{tabular}{|c|c|c|c|c|c|c|c|c|c|}
\hline & $B$ & & 24,8 & 20,8 & - & - & - & - & - \\
\hline & C & & 99 & 88 & - & - & - & - & - \\
\hline \multirow{3}{*}{ RP } & A & & $\begin{array}{r}1.717 .4 \\
25\end{array}$ & $\begin{array}{r}4121.3 \\
55\end{array}$ & $\begin{array}{r}6 \\
012450\end{array}$ & - & - & - & - \\
\hline & B & & 7,2 & 16,9 & 21,4 & - & - & - & - \\
\hline & $C$ & & - & 62 & 158 & - & - & - & - \\
\hline \multirow{3}{*}{ CHP } & A & & & & $\begin{array}{r}3.011 .07 \\
6\end{array}$ & $\begin{array}{r}2.716 . \\
094\end{array}$ & $\begin{array}{r}6.113 . \\
352\end{array}$ & $\begin{array}{r}7.317 .8 \\
08\end{array}$ & $\begin{array}{r}11.155 . \\
972\end{array}$ \\
\hline & $B$ & & & & 10,7 & 8,7 & 19,4 & 20,9 & 26,0 \\
\hline & C & & & & 49 & - & 178 & 112 & 135 \\
\hline \multirow{3}{*}{ MHP } & A & - & - & - & $\begin{array}{r}2.301 .34 \\
3\end{array}$ & $\begin{array}{r}5.606 . \\
583\end{array}$ & $\begin{array}{r}2.635 . \\
787\end{array}$ & $\begin{array}{r}5.001 .8 \\
69\end{array}$ & $\begin{array}{r}5.585 .5 \\
13\end{array}$ \\
\hline & $B$ & - & - & - & 8,2 & 18,0 & 8,4 & 14,3 & 13,0 \\
\hline & C & - & - & - & - & 129 & - & 71 & 53 \\
\hline \multirow{3}{*}{ FP } & A & - & - & - & - & $\begin{array}{r}4.805 . \\
381\end{array}$ & - & - & - \\
\hline & $B$ & - & - & - & - & 15,4 & - & - & - \\
\hline & $C$ & - & - & - & - & 111 & - & - & - \\
\hline \multirow{3}{*}{$\begin{array}{l}\text { AK } \\
\text { PARTY }\end{array}$} & A & - & - & - & - & - & $\begin{array}{r}10.808 \\
.229\end{array}$ & $\begin{array}{r}16.327 . \\
291\end{array}$ & $\begin{array}{r}21.399 . \\
082\end{array}$ \\
\hline & B & - & - & - & - & - & 34,3 & 46,6 & 49,8 \\
\hline & C & - & - & - & - & - & 363 & 341 & 327 \\
\hline \multirow{3}{*}{$\begin{array}{l}\text { INDEPEN } \\
\text { DENTS }\end{array}$} & A & $\begin{array}{r}195.58 \\
8\end{array}$ & 89. 421 & 32.721 & 133.895 & $\begin{array}{r}270.2 \\
65\end{array}$ & $\begin{array}{r}314.25 \\
1\end{array}$ & $\begin{array}{r}1.835 .4 \\
86\end{array}$ & $\begin{array}{r}2.819 .9 \\
17\end{array}$ \\
\hline & B & 1,1 & 0,4 & 0,1 & 0,5 & 0,9 & 1,0 & 5,2 & 6,6 \\
\hline & C & - & - & - & - & 3 & 9 & 26 & 35 \\
\hline \multirow{3}{*}{$\begin{array}{l}\text { OTHER } \\
\text { PARTIES }\end{array}$} & A & - & $\begin{array}{r}897.79 \\
0\end{array}$ & $\begin{array}{r}108.36 \\
9\end{array}$ & $\begin{array}{r}3.858 .25 \\
0\end{array}$ & $\begin{array}{r}5.714 . \\
251\end{array}$ & $\begin{array}{r}14.292 \\
.951\end{array}$ & $\begin{array}{r}4.567 .2 \\
37\end{array}$ & $\begin{array}{r}1.981 .2 \\
79\end{array}$ \\
\hline & B & - & 3,7 & 0,4 & 14,0 & 18,3 & 45,3 & 13,0 & 4,6 \\
\hline & C & - & - & - & - & - & - & - & \\
\hline
\end{tabular}

Sayfa | 796 
Figure 2: (TUİK)

SYMBOLS AND ABBREVATIONS
A. Number of votes
B. Vote rate
C. Number of Deputy

AK PARTI (Justice and Development Party), ANAP (Motherland Party)

CHP (Republican People's Party), DSP (Democratic Left Party)

DYP (True Path Party), FP (Virtue Party), HP (Populist Party), MDP (Nationalist Democracy Party)

MHP (Nationalist Movement Party), RP (Welfare Party), SHP (Social Democratic Populist Party)

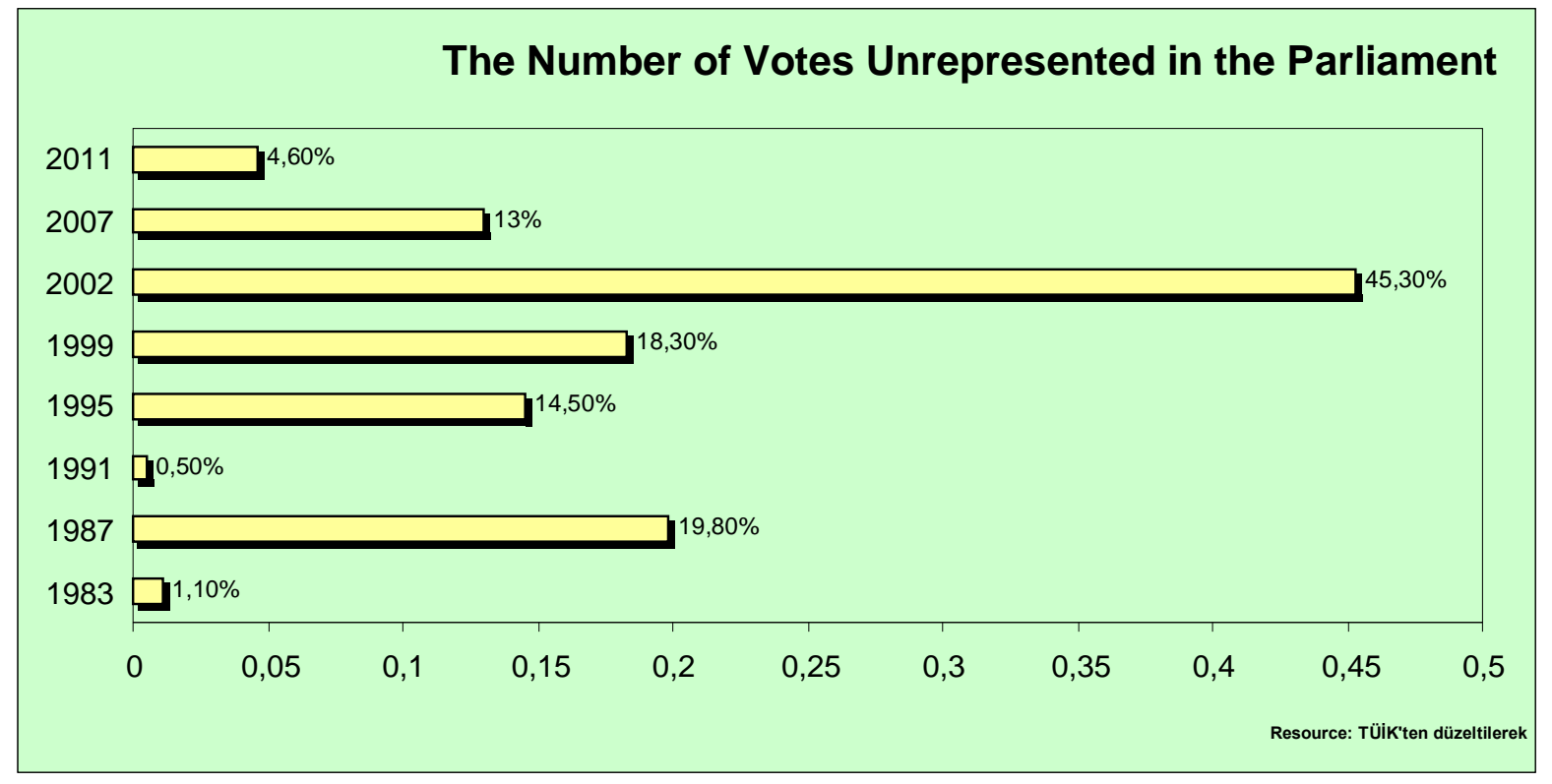

Figure 3: The Number of Votes Unrepresented in the Parliament

As is seen, as the number of the parties taking part in the parliament decreases the rate of unrepresented vote increases; the problem of fairness in representation is seen. The fact that $45,3 \%$ of the votes couldn't be represented in 2002 elections is the situation that attracted the greatest attention. In this election only two parties could enter the parliament. In the election periods when there are parties whose vote rates are around 7$8 \%$ or over $9 \%$ but that couldn't pass over the threshold, there are some parties that came to power by increasing their number of deputies though their votes did not increase proportionally.

\section{Result}

The high election threshold which is in use in Turkey as a heritage of the period after 1980 creates a justice problem in essence. This application is after all the result of the prohibitive mentality that determines the political life seen after 1980. Military government became effective also in the period 
of transition to civil life after three years of military government by means of some regulations such as vetoing the parties that would take part in the elections, and the candidates determined by the parties and imposing ban for the people who were interested in policy before 1980. Albeit, with the presence of the governments which couldn't find a solution to economic and social problems and thus frequently changed before 1980 and with the effect of coalition experiences not going well stability factor was brought to forefront. Claiming that it would lead to the emergence of single-party government, the high threshold was implemented with the purpose of eliminating the small parties. The absence of fairness in representation for the sake of governmental stability is at least as important as governmental stability because the voters may move away from voting as the party they vote for may not pass over the threshold. Also when they are not represented in the parliament even if they vote, the sense of justice does not form in the society/ public conscious.

Contemporary democracy is a regime in which the political participation of the citizens is not reduced just to voting; voters are able to control the governors besides electing them. Also, the understanding of democracy in our present day is a "pluralistic" one and it is defined as the view that rights and freedoms of minorities must be protected from the majority. Lately, as the concepts of plurality and participation are the matters of social and political development it is obvious that election system must also be regulated accordingly. There is an important problem if the leader/party that represents the majority in the parliament has the possibility of an exaggerated representation and turned it to a despotic attitude however he /it did not reach this with a very high vote rate but with the regulations in the election system.

The implementation of the threshold of 105 in Turkey is an important problem in terms of the principle of justice. It is necessary to decrease the threshold to $5 \%$ or below in respect to the purpose of being a contemporary democracy.

It is no doubt that no election system can ensure the representation of all the votes in the parliament. However, beginning the work with the evaluation of how the principles of governmental stability and fairness in representation are handled, it must be regarded that these are not two alternatives but they are the purpose that must be together.

If the fairness in representation is provided the level of participation to political life increase and social life is be prepossessed by it. Fairness in 
representation is as important/necessary as the principle of governmental stability.

\section{BIBLIOGRAPHY}

Aytaç, A. M. (2011). Temsilde Adalet Kavramlar, Kuramlar. Diyalog 8, 1117.

Bora, T. (2011). Tarhan Erdem'le Söyleşi - Katılımın Başlıca Engeli Anayasadır. Diyalog 8, 18-22.

Çavdar, T. (1987). Müntehib-i Sani'den Seçmene. Ankara: V Yayınları.

Duverger, M. (1986). Siyasal Rejimler. İstanbul: Sosyal Yayınları.

Kaboğlu, İ. Ö. (1994) Özgürlükler Hukuku İnsan Haklarının Hukuksal Yapısı Üzerine Bir Deneme. İstanbul: AFA Yayını.

Kili, S. \& Gözübüyük, Ş. (2000). Türk Anayasa Metinleri (Sened-i İttifaktan Günümüze) Yenilenmiş 2. Baskı. İstanbul: İş Bankası Kültür Yayınları.

Özbudun, E. (1990). Türk Anayasa Hukuku. Ankara: Yetkin Yayını.

Selçuk, S. (1987). Temsili ve Katılımcı Demokrasinin Kökeni. İstanbul: Çağdaş Yayınları.

Sezen, S. (2000). Seçim ve Demokrasi. İstanbul: Gündoğan Yayınları.

Subaşat, T. (2015). Başkanlık Sistemiyle Türkiye Daha Hızlı Büyür mü?. Íktisat ve Toplum Sayı 52, 19-22.

Tanilli, S. (1985). Devlet ve Demokrasi Anayasa Hukukuna Giriş. (4.baskı). İstanbul: Say Yayınları,

Touraine, A. (1997). Demokrasi Nedir?. İstanbul: Yapı Kredi Yayınları.

Tuncer, E. (2006). Türkiye'de Seçim Uygulamaları/Sorunları Işığında Temsilde Adalet-Yönetimde İstikrar İlkelerinin İşlevselliği. Erişim Adresi: www.tesav.org.tr

Türkmen G. \& Yetkin, Ç. (2011) Seçim Barajını "Yönetimde İstikrarı Azaltmayan Bir Seviyeye" Düşürmek Mümkün mü?. Erişim Adresi: www.tepav.org.tr

EXTENDED ABSTRACT: Democracy is a regime in which the rulers are elected by the ruled. Although democracy, which is the ideal regime at this point, has various forms such as direct democracy, representative democracy, and social democracy, the idea of "participatory" and "pluralistic" democracy currently predominates. The importance of political participation in democracies is unquestionable. The election is not the only way of political participation, but many citizens may be contented with participating as "voters". The majority believes and is contented with the idea that they fulfilled their duty as a voter when the "right to vote and to stand as a candidate", which is among the fundamental rights, is exercised. Democracy depends on raising awareness of the public about rights and freedoms; raising 
awareness depends on the extent of the turnout. In a democratic society, just like individuals' fundamental rights are guaranteed, the individuals must also participate in social life as citizens. Respect for fundamental rights, citizenship and representation of the rulers, and the interdependence between these constitutes democracy. Since civil society consists of many social actors, democracy allows for representation only to the extent that it is pluralistic. Societies in which the mechanisms of participation are kept open in a way that citizens, who exercise their right to vote and to stand as a candidate can convey the needs and demands of the civil society to the rulers they elected and where there is a pluralistic structure, have a democratic functioning mechanism. In order to exercise political rights, one must be a citizen of a state. Political rights are guaranteed in constitutions and supranational texts. In addition, it can be stated that an audit mechanism has been established through the observations of international organizations regarding the exercising of these rights and this may positively affect the credibility of the elections. Article 67 of the 1982 Constitution is about the citizens' right to vote, to stand as a candidate, to engage in a political activity independently or within a political party, and to participate in the referendum in accordance with the conditions set forth in the law. Elections and referendum are held under judicial administration and supervision on the basis of free, equal, secret, direct ballot and universal suffrage, open counting and tabulation. The exercise of these rights is determined by the law. On the other hand, election laws are prepared such that they reconcile the principles of "fair representation" and "administrative stability". Despite this provision in the constitution, it is not possible to see these principles together in practice. It is seen that the electoral systems used have an influence on this. Depending on which electoral system (majority system or proportional representation system) is preferred and how it is implemented (whether there is a threshold or the percentage if any), the reflection of voting rates in the parliament may change. In elections, some parties may be represented above the rate of votes they obtain (overrepresentation), some parties may be represented below the rate of votes (underrepresentation), and some parties may stay out of the parliament because their votes are insufficient. While the rates of over or underrepresentation are low in systems that prioritize the principle of "fair representation"; they become higher in electoral systems that emphasize the principle of "administrative stability". The debate on fairness in representation is not theoretical, it is important, and related to the tangible problems seen in social life. The electoral system, which is a technical arrangement, determines whether the reflection of the votes to the parliament creates a fair representation. The same distribution of votes may result in a different parliamentary structure, depending on the application of the proportional representation or majoritarian system. Therefore, it is possible to evaluate the struggle for fair representation, particularly against electoral thresholds, as an expression of the demand for equality in the democratic system. Electoral systems are classified into majoritarian system and proportional representation system. It can be stated that the majoritarian system was implemented first, followed by the adoption of the proportional representation system, and occasionally a mixture of 
the two systems is implemented as the electoral system. The majoritarian system is divided into "at-large" and "single-winner" (small district) representation according to the size of the electoral districts. The majoritarian system is simple to implement, it increases participation, and stability is achieved as there is generally the ruling and opposition party in the parliament. Since there is no need for a coalition, balanced decisions made within the government itself increase the confidence of the governed. However, there is also the possibility that the majority government may adopt a repressive attitude by abusing power and relying on the parliamentary majority. The point to be emphasized is that a strong government with a parliamentary majority is preferred in terms of stability but the voters expect that their votes are reflected in the parliament. Since society would like to see the institutionalization of justice in the legislature, too many extraparliamentary votes create difficulties. Proportional representation, on the other hand, means that the number of parliament members from each party is in proportion to the votes each party gets. Proportional representation can be in the form of "the largest remainder", "national remainder" or "d'Hondt system", depending on how "remainder votes" will be distributed. In Turkey, "d'Hondt system with threshold" is implemented since 1968. There is no doubt that the threshold favors the large parties. Proportional representation is a good system in terms of fair representation, as it allows each party to be represented in proportion to its votes. The number of unrepresented votes is low, overrepresentation is very rare, representation of each opinion, ie democratic pluralism, is possible. It has disadvantages such as the tendency for the number of parties to increase and instability created by coalitions if a single party cannot provide the majority in the parliament. Since either of the fair representation and administrative stability principles come to the fore due to the characteristics of the electoral systems, which electoral system is implemented in Turkey and the evaluations on its impact are also important. However, the ten percent threshold, which the public finds very high, is an important problem in terms of the principle of fair representation. It is widely accepted that it is necessary to lower the electoral threshold below five percent.

GENİ̧̧LETÍLMIŞ ÖZ: Demokrasi, yönetenlerin yönetilenler tarafından seçildiği bir rejimdir. Gelinen noktada ideal rejim olan demokrasinin doğrudan demokrasi, temsili demokrasi, sosyal demokrasi gibi çeşitleri bulunmakla birlikte, günümüzde "katılımcı" ve "çoğulcu" demokrasi anlayışı hakimdir. Demokrasilerde siyasal katılımın önemi, tartışılmazdır. Seçim, siyasal katılımın tek yolu değildir ama birçok yurttaş "seçmen" olarak katılma durumu ile yetinebilmektedir. Temel haklar arasında yer alan "seçme ve seçilme hakkı" kullanıldığında, seçmen olarak görevini yaptığını düşünenler, bununla yetinenler çoğunluktadır. Demokrasi, halkın hak ve özgürlükler konusunda bilinçlenmesine; bilinçlenmesi de katılımın yaygınlığına bağlıdır. Demokratik bir toplumda bireylerin temel hakları güvence altına alındığı gibi, yurttaş olarak toplumsal yaşama katılmaları da gerekir. Temel haklara saygı, yurttaşlık ve yöneticilerin temsilciliği; bunlar arasında karşılıklı bağımlılık ilişkisi, demokrasiyi oluşturur. Sivil toplum pek çok toplumsal aktörden oluştuğuna göre, 
demokrasi ancak çoğulcu olduğu ölçüde temsilciliğe olanak sağlar. Seçme ve seçilme hakkını kullanan yurttaşların, sivil toplumun intiyaç ve taleplerini, seçtikleri yönetenlere iletebilecek biçimde katıım mekanizmalarının açık tutulduğu, çoğulcu bir yapının olduğu toplumlar, demokratik işleyişe sahiptir. Siyasal hakları kullanabilmek için, bir devletin yurttaşı olmak gerekmektedir. Siyasal haklar, anayasalarda ve ulus-üstü metinlerde güvence altına alınmıştır. Ayrıca bu hakların kullanımına ilişkin uluslararası kuruluşların gözlemleri ile denetim mekanizması kurulduğu ve bunun seçimlerin güvenirliğini olumlu etkileyebileceği de belirtilebilir. 1982 Anayasasında 67.madde vatandaşların kanunda gösterilen şartlara uygun olarak, seçme, seçilme ve bağımsız olarak veya bir siyasi parti içinde siyasi faaliyette bulunma ve halk oylamasına katılma hakkına ilişkindir. Seçimler ve halk oylaması; serbest, eşit, gizli, tek dereceli, genel oy, açık sayım ve döküm esaslarına göre, yargı yönetim ve denetimi altında yapılır. Bu hakların kullanımı, kanunla belirlenir. Seçim kanunları ise, "temsilde adalet" ve "yönetimde istikrar" ilkelerini bağdaştıracak biçimde düzenlenir. Anayasadaki bu hükme rağmen, uygulamada bu ilkeleri bir arada görmek olanaklı değildir. Bunda uygulanan seçim sistemlerinin etkisi olduğu görülmektedir. Seçim sistemlerinin hangisinin (çoğunluk sistemi mi, nispi temsil sistemi mi) tercih edildiğine ve nasıl uygulandığına (baraj uygulaması olup olmadığı, varsa oranına) göre, oy oranlarının parlamentoya yansıması değişebilmektedir. Seçimlerde bazı partiler, elde ettikleri oy oranının üzerinde (aşkın temsil), bazı partiler oy oranının altında (eksik temsil) temsil edilebilmekte, bazı partiler ise, aldıkları oy yetersiz olduğu için parlamento dışında kalabilmektedir. Aşkın ya da eksik temsil, "temsilde adalet" ilkesine öncelik veren sistemlerde düşük düzeyde iken; "yönetimde istikrar" ilkesini öne çıkaran seçim sitemlerinde büyümektedir. Temsil adaleti tartışması, teorik değil; toplumsal yaşamda görülen somut sorunlarla ilgili ve önemlidir. Teknik bir düzenleme olan seçim sistemi, oyların parlamentoya yansımasının, adaletli bir temsil ortaya çıkarıp çıkarmadığını belirler. Aynı oy dağıımı, nispi temsil veya çoğunluk sisteminin uygulanmasına göre, farklı bir parlamento yapısı ortaya çıkarabilir. Bu nedenle, temsilde adaletle ilgili özellikle seçim barajlarına karşı verilen mücadelenin, eşitlik talebinin demokratik sistemde ifadesi olarak değerlendirilmesi olanaklıdır. Seçim sistemleri, çoğunluk sistemi ve nispi temsil sistemi olarak ayrılır. Önce çoğunluk sisteminin uygulandığı, daha sonra nispi temsil sistemine geçildiği ve bazen de iki sistemin karması biçiminde seçim sistemlerinin uygulandığı belirtilebilir. Çoğunluk sistemi, seçim çevrelerinin büyüklüğüne göre, "liste usulü" ve "tek isim" (dar bölge) usulü olarak ikiye ayrılır. Çoğunluk sisteminin uygulanması basittir, katılımı artırır, parlamentoda genel olarak iktidar ve muhalefet partisi olduğu için, istikrar sağlanır. Koalisyona gerek kalmadığı için de kurulan hükümetlerin kendi içinde dengeli kararlar alması, yönetilenlerde güveni artırır. Ancak, çoğunluğa sahip hükümetin, iktidarı kötüye kullanarak, parlamento çoğunluğuna dayanarak, baskıcı bir tutum sergileme olasılığı da vardır. Özellikle vurgulanması gereken nokta, meclis çoğunluğuna sahip güçlü bir hükümet, istikrar açısından tercih edilmekle birlikte, oy verenlerin beklentisi de oylarının parlamentoya yansımasıdır. Toplum, adaletin yasama organında da kurumsallaşmasını görmek isteyeceği için, parlamento dışında kalan oyların fazla olması, sıkıntı yaratır. Nispi temsil ise, her 
partinin aldığı oy oranında milletvekili çıkarmasıdır. Nispi temsil ise, "artık oylar"ın nasıl dağıtılacağına göre, "en büyük artık", "milli bakiye" veya "d'Hondt sistemi" şeklinde olabilir. Türkiye'de 1968'den beri, "barajlı d'Hondt sistemi" uygulanmaktadır. Barajın büyük partiler yararına olduğu, kuşkusuzdur. Nispi temsil, her partiye aldığı oy oranında temsil edilme olanağı verdiği için, temsilde eşitlik bakımından adil bir sistemdir. Temsil edilmeyen oy sayısı düşüktür, aşırı temsil çok seyrek, her bir görüşün temsil olanağı yani demokratik çoğulculuk mümkündür. Parti sayısının artması eğilimi ve özellikle parlamentoda tek bir partinin çoğunluğu sağlayamaması durumunda ise, koalisyonların yaratacağı istikrarsızlık gibi olumsuzluklar yaşanır. Seçim sistemlerinin özellikleri gereği, temsilde adalet ve yönetimde istikrar ilkelerinden biri öne çıktığı için, Türkiye'deki seçim dönemlerinde hangi seçim sisteminin uygulandığı ve bunun etkisi konusunda yapılan değerlendirmeler de önem taşımaktadır. Ancak, özellikle kamuoyunda çok yüksek bulunan yüzde onluk ülke barajı, temsilde adalet ilkesi açısından önemli bir sorundur. Ülke seçim barajının yüzde beşin altına düşürmenin gerekliliği, yaygın kabul görmektedir. 